\title{
Effect of Early versus Late Cord Clamping of Term Infants on Maternal and Neonatal Outcomes
}

\author{
Heba A. I.1 , Galal A. E. 2 , Amal A. O. 3 and Aziza I. M.3
}

Specialized Nurse in AL-Mansoura Fever Hospital, Egypt. (2) Obstetrics \&gynecology, Faculty of Medicine, Benha University, Egypt. 2 Obstetrics \&gynecology, Faculty of Nursing, Benha University, Egypt.

\begin{abstract}
Aim: The current study aimed to study the effect of early versus late cord clamping of term infants on maternal and neonatal outcomes. Design: A quasi-experimental study design was used. Setting : Labour ward affiliated at Obstetrics and Gynecology department at Benha University Hospital. Sampling: Purposive sample included 340 women divided into 2 equal groups (group1 early cord clamping and group2 late cord clamping).Tools of data collection: I-Structured interviewing questionnaire sheet consisted of two parts. II- Maternal outcomes measures. IIINeonatal outcomes measures. Result. There was no statistical significant difference between early and late cord clamping regarding the duration of different stages of labor and postpartum laboratory investigation findings including maternal hemoglobin level and hematocrit at birth, and after four hours. There was a highly statistical significant difference $(\mathrm{p}<0.001)$ between early and late cord clamping groups in relation to neonatal hemoglobin, hematocrit, and ferritin. There was no statistical significant difference $(p>0.05)$ between both groups regarding total bilirubin after 4 hours. Conclusion: delayed cord clamping improves neonatal hemoglobin and ferritin levels without causing any harm to maternal or neonatal outcomes. Also delayed cord clamping doesn't increase postpartum hemorrhage or duration of third stage of labour. Recommendation: increasing awareness of the routine delayed cord clamping by obstetricians and midwives to achieve mothers and neonates benefit.
\end{abstract}

Key words: cord clamping, maternal outcomes, neonatal outcome.

Introduction

The conversion from fetal to neonatal life represents one of the greatest physiological challenges that any human will encounter. Once the umbilical cord is clamped, neonates must clear their airways of liquid to allow the onset of pulmonary gas exchange and the cardiovascular system must experience a major structural and functional reorganization. Although it is well recognized that the cardiovascular transition at birth is triggered by lung aeration (Hooper et al., 2015).

Immediately after childbirth, the cord pulsates and placenta continues providing oxygen, red blood cells, stem cells, immune cells, and blood volume to the baby. This transfer of blood is called placental transfusion, that is facilitated by delayed cord clamping and can ensure safe oxygen level and blood volume for the neonate (Mercer et al., 2008). Early cord clamping deprives the neonate from 
the oxygen-rich placental blood that tides the newborn over until breathing is well establish (Brucker, 2009).

In term infants, one-minute delay in cord clamping after birth leads to an additional $80 \mathrm{~mL}$ of blood from the placenta to the infant's circulation, which increases to about $100 \mathrm{~mL}$ by 3 minutes after birth. This additional blood (plasma and the red cell mass) adds to extra iron, amounting to $40-50 \mathrm{mg} / \mathrm{kg}$ of body weight. Such supplemental iron from placental transfusion combined with the approximately $75 \mathrm{mg} / \mathrm{kg}$ of body iron present at birth in a full-term newborn, may help prevent iron deficiency during the first year of life (Eichenbaum-Pikser \& Zasloff, 2009).

Recently WHO updated its guidelines on preventing Postpartum Haemorrhage( WHO, 2012). The International Confederation of Midwives and the International Federation of Gynecology and Obstetrics also updated its statement on PPH in 2006 (ICM/FIGO, 2006) . WHO recommend cord clamping one to three minutes after the birth

\section{Aim of The Study}

The aim of this study was to study the effect of early versus late cord clamping of term infants on maternal and neonatal outcomes.

\section{Research Hypothesis}

Late cord clamping ( at 1 to 3 minutes after birth) in healthy term neonates:

- increase hematocrite, hemoglobin, and ferritin within physiologic ranges and does not cause pathological jaundice.
- does not increase the risk of maternal postpartum hemorrhage or duration of the third stage of labour and does not decrease maternal hematocrite and hemoglobin at birth and after 4 hours of delivery.

\section{Subjects And Method}

Design: A Quasi-experimental design was applied

Setting: The study was conducted at labour ward affiliated at Obstetrics and Gynecology department at Benha University Hospital.

Sample type: Purposive sample was taken from parturient women coming to labour ward in Benha University Hospital during the third stage of labour.

Sample size: The total number was calculated based on the previous year census report of the Obstetrics and Gynecology department at Benha University Hospital utilizing the following formula:

$\mathrm{n}=$ where $: \mathrm{n}=$ sample size $\mathrm{N}=$ total number of normal vaginal delivery (2305) $\mathrm{e}=$ margin $\operatorname{error}(0.05)$

thus sample size $=340$ women .

\section{Sample criteria:}

- $\quad$ Primi para.

- $\quad$ Term pregnancy $(>37 \mathrm{~W})$

- Normal labour (Vertex presentation).

- $\quad$ Free from any medical disease

- $\quad$ singleton pregnancy 


\section{sample technique:}

A total sample from the previously mentioned setting was divided randomly into two groups: a study group 1 early umbilical cord clamping group and a study group 2 delayed umbilical cord clamping group. In the first the early umbilical cord clamping group are collected then delayed umbilical cord clamping group according to previous mentioned criteria

In the study group 1 , doctors must wait at least 15-30 second before umbilical cord clamping during third stage of labour. In the study group 2, the women received short and easy understandable information regarding the possible benefits of late cord clamping . In this group, doctors must wait at least 1 minutes before cord clamping

\section{Tools of data collection:}

\section{Questionnaire : \\ I): Structured Interview} structured interview questionnaire) consisted of the two parts:

1. Socio-demographic characteristic include (age, level of education, occupation, and residence).

2. Obstetric history include( gestational age, duration of third stage of labour, receiving oxytocin before cord clamping).

\section{II :. Maternal outcomes measurements}

This tool was designed and used to assess the necessary data about maternal outcomes which includes the following ( maternal blood loss, maternal hemoglobin and hematocrite \{at birth and after 4 hours\}, maternal RH, manual removal of placenta, need for blood transfusion, and incidence of $\mathrm{PPH}$ according to amount of blood in soaked pad at $1^{\text {st }}$ hour after delivery

\section{III : Neonatal outcomes measurements.}

This tool was used to assess and collect the necessary data about neonatal outcomes which includes the followings ( Apgar score 1\& 5 minutes, birth weight, neonatal\{ hemoglobin, hematocrite, ferritin, and bilirubin $\}$ at birth and after $4 \mathrm{hrs}$ and admission to NNICU.

\section{Content Validity:}

- The validity of the tools was ascertained by a panel of 3 experts of professors from the obstetric department, faculty of medicine and faculty of nursing Benha University who reviewed the tools for content and internal validity

- The reliability test of the tools was done with the cronbach alpha test, Maternal outcomes measurements(0.79) and Neonatal outcomes measurement (0.91).

\section{Ethical consideration:}

- The aim of the study was explained to each woman before applying the tools to gain their confidence and trust.

- An oral consent was obtained from each women to participate in the study and withdraw when she needs. 
- The study had no physical, social or psychological risks on the participant.

- The data was collected and treated confidentially.

- Each study subject was informed about time throughout the study.

\section{2- OPERATIONAL DESGIN :}

\section{- Preparatory phase}

- A review of current and past national and international relevant literature covering the various aspects of the study was done using local and international books, magazines, articles, and computer search was done to develop the study tools and contents.

\section{- Pilot Study}

A pilot study was conducted to test the clarity and applicability of the tools, and to estimate the time needed for data collection. It was conducted on $10 \%$ of the total sample(34 parturient women). No modifications done so the sample of pilot study was included in the main study sample.

\section{work) \\ - Implementation phase (Field}

Collection of data started from beginning of December 2016 until the middle of June 2017 at the study setting which was visited 3 days weekly. The implementation phase was carried out during natal and postnatal periods of labour.

\section{- During natal period:}

\section{- Interview}

The researcher introduces herself to the participant parturient women, taking oral consent of women to participate in the study. The interview questionnaire was conducted for selected women. Each interview was completed during the period of 20 minutes in which data related to socio-demographic characteristics were collected e.g. age, occupation, level of education, present medical history, family history, and data about obstetric history.

\section{- Intervention}

During the labour in both group before cutting of cord the neonate was held at $20 \mathrm{~cm}$ below the vulva for 20 seconds. This was done to perform the main study intervention either early or late clamping and withdraw blood sample from the women at birth and after 4 hours and her baby after 4 hrs. The neonatal blood sample was analyzed for hemoglobin, hematocrite, iron status (serum ferritin), and bilirubin and the maternal blood sample was analyzed for hemoglobin and hematocrite. Blood sample was collected in EDTA tube for complete blood count, and in serum separator tubes for serum ferritin and bilirubin.

Women assigned to study group 1 and study group 2 should receive short and easy information regarding the possible benefits of the early and late umbilical cord clamping, and encourage them to participate. In most cases, women were apprehensive and anxious about the research aim, but they refuse to participate and excluded then taken another participant 


\section{- During postnatal period}

Initial assessment of the neonate condition using Apgar score

The Apgar score is determined by evaluating the neonate baby at the first and the fifth minutes after birth using 5 parameters (Appearance, Pulse, Grimace, Activity and Respiration) on a scale from zero to two, then summing up the five values.

\section{- Administrative Design}

Formal letters were issued from the dean of the Faculty of Nursing, to director of Benha University hospital to conduct the study.

\section{- Statistical Design:}

Data were verified prior to computerized entry. The statistical package for social science (SPSS version 20) was used for that purpose, followed by data tabulation and analysis.
Descriptive statistics were applied (e.g. frequency, percentages, mean, standard deviation). Test of significance (chisquare and fisher exact test, Pearson correlation were used. A statistically significant level was considered when $\mathrm{p}<0.05$, and a highly statistically significant level was considered when $\mathrm{p}<0.001$

\section{Limitations of the study.}

- One limitation in this study was haemolysis of blood sample especially neonatal blood sample and this lead to exclude the sample and withdraw another sample for about 10 cases

- There was difficulty in taking neonate's sample due to the refusal of the mother in about 23 case

- Difficulty in taking second sample from the mothers after $4 \mathrm{hrs}$ also due to the refusal of them in about 11 case 
Results

Table (1): Distribution of the studied subjects regarding their socio-demographic characteristics $(\mathrm{N}=340)$

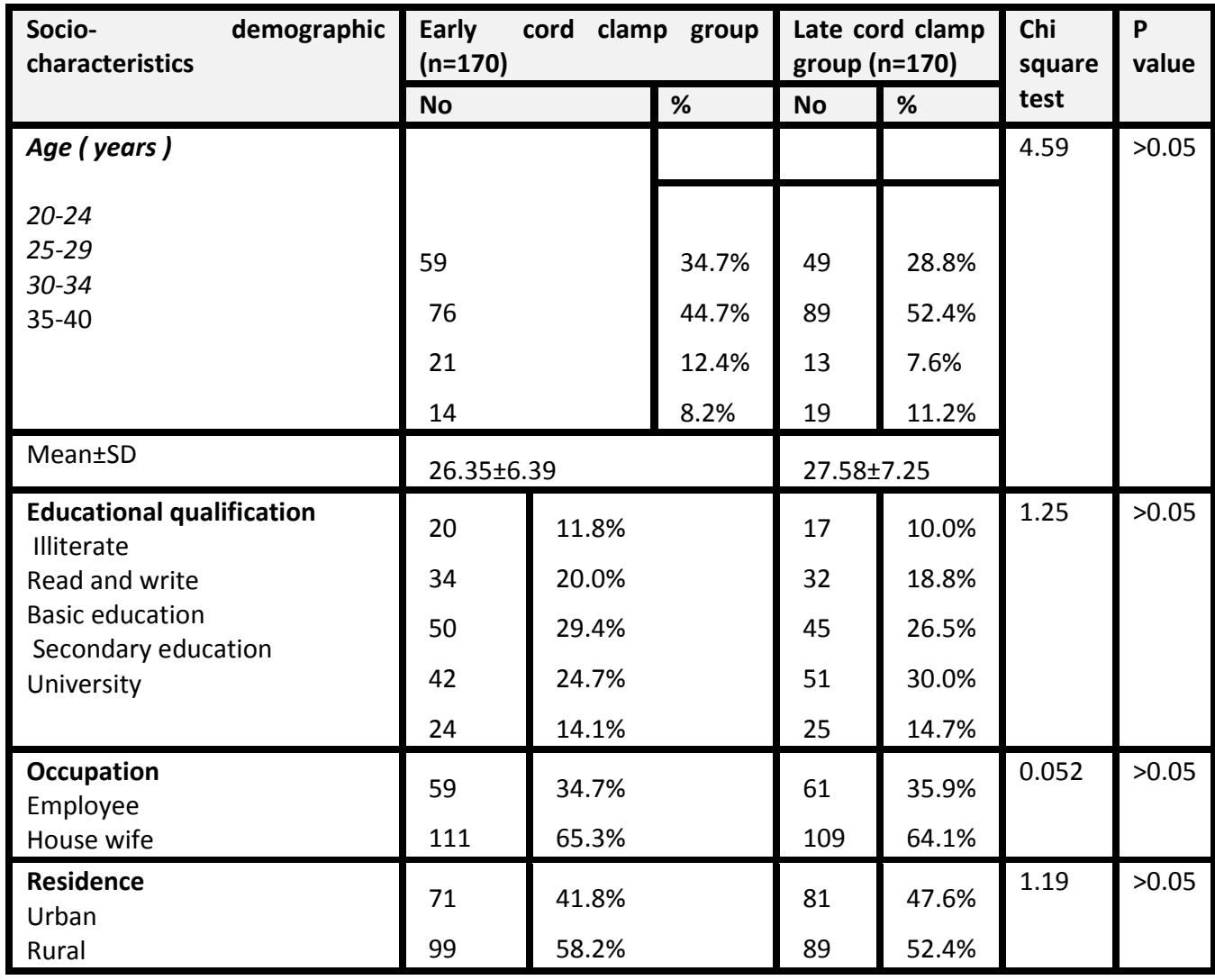

Table (1): illustrates no statistically significant differences between studied subjects between both early and late cord clamping in relation to their age, educational qualification, occupation and residence ( $\mathrm{p}->0.05)$. 
Table (2): Distribution of postpartum laboratory investigation findings among the studied subjects $(n=340)$

\begin{tabular}{|c|c|c|c|c|c|c|}
\hline & \multicolumn{2}{|c|}{$\begin{array}{l}\text { Early cord } \\
\text { clamp } \\
\text { group }(n=170)\end{array}$} & \multicolumn{2}{|c|}{$\begin{array}{l}\text { Late cord clamp } \\
\text { group }(n=170)\end{array}$} & \multirow[t]{2}{*}{$\begin{array}{l}\text { Chi } \\
\text { square } \\
\text { test }\end{array}$} & \multirow[t]{2}{*}{$P$ value } \\
\hline & No & $\%$ & No & $\%$ & & \\
\hline $\begin{array}{l}\text { Maternal hemoglobin level (At birth) } \\
\text { less than } 10 \mathrm{~g} / \mathrm{dl} \\
\text { from } 10-12 \mathrm{~g} / \mathrm{dl} \\
\text { More than } 12 \mathrm{~g} /\end{array}$ & $\begin{array}{l}6 \\
104 \\
60\end{array}$ & $\begin{array}{l}3.5 \% \\
61.2 \% \\
35.3 \%\end{array}$ & $\begin{array}{l}4 \\
91 \\
75\end{array}$ & $\begin{array}{l}2.4 \% \\
53.5 \% \\
44.1 \% \\
\end{array}$ & 2.93 & $>0.05$ \\
\hline $\begin{array}{l}\text { Maternal hemoglobin level (After } 4 \\
\text { hours) } \\
\text { less than } 10 \mathrm{~g} / \mathrm{dl} \\
\text { from } 10-12 \mathrm{~g} / \mathrm{dl} \\
\text { More than } 12 \mathrm{~g} /\end{array}$ & $\begin{array}{l}32 \\
118 \\
20\end{array}$ & $\begin{array}{l}18.8 \% \\
69.4 \% \\
11.8 \%\end{array}$ & $\begin{array}{l}26 \\
113 \\
31\end{array}$ & $\begin{array}{l}15.3 \% \\
66.5 \% \\
18.2 \% \\
\end{array}$ & 3.10 & $>0.05$ \\
\hline $\begin{array}{l}\text { Maternal hematocrit (At birth) } \\
\text { less than } 35 \% \\
\text { From } 35-47 \% \\
\text { More } 47 \%\end{array}$ & $\begin{array}{l}55 \\
73 \\
42\end{array}$ & $\begin{array}{l}32.4 \% \\
42.9 \% \\
24.7 \%\end{array}$ & $\begin{array}{l}47 \\
81 \\
42\end{array}$ & $\begin{array}{l}27.6 \% \\
47.6 \% \\
24.7 \%\end{array}$ & 1.04 & $>0.05$ \\
\hline $\begin{array}{l}\text { Maternal hematocrits level (After } 4 \\
\text { hours) } \\
\text { less than35\% } \\
\text { From35-47\% } \\
\text { More than } 47 \%\end{array}$ & $\begin{array}{l}54 \\
92 \\
24\end{array}$ & $\begin{array}{l}31.8 \% \\
54.1 \% \\
14.1 \% \\
\end{array}$ & $\begin{array}{l}39 \\
101 \\
30\end{array}$ & $\begin{array}{l}22.9 \% \\
59.4 \% \\
17.6 \% \\
\end{array}$ & 3.50 & $>0.05$ \\
\hline
\end{tabular}

Table (2):reveals no statistically significant differences between studied subjects at early and late cord clamping regarding postpartum laboratory findings including maternal hemoglobin level and hematocrit at birth, and after four hours ( $p>0.05$ 
subjects $(n=340)$

Table(3) :Distribution of postpartum related outcomes among the studied

\begin{tabular}{|c|c|c|c|c|c|c|}
\hline & \multicolumn{2}{|c|}{$\begin{array}{l}\text { Early cord } \\
\text { clamp } \\
\text { group }(n=170)\end{array}$} & \multicolumn{2}{|c|}{$\begin{array}{l}\text { Late cord clamp } \\
\text { group }(n=170)\end{array}$} & \multirow[t]{2}{*}{$\begin{array}{l}\text { Chi } \\
\text { square } \\
\text { test }\end{array}$} & \multirow[t]{2}{*}{$P$ value } \\
\hline & No & $\%$ & No & $\%$ & & \\
\hline $\begin{array}{l}\text { Maternal blood loss at delivery } \\
\text { No (blood loss less than } 500 \mathrm{ml} \text { ) } \\
\text { Moderate (blood loss } 500-1000 \\
\text { ml) }\end{array}$ & $\begin{array}{l}67 \\
103\end{array}$ & $\begin{array}{l}39.4 \% \\
60.6 \%\end{array}$ & $\begin{array}{l}104 \\
66\end{array}$ & $\begin{array}{l}61.2 \% \\
38.8 \%\end{array}$ & 16.10 & $<0.001^{* *}$ \\
\hline $\begin{array}{l}\text { Women need for manual } \\
\text { removal of the placenta } \\
\text { Yes } \\
\text { No }\end{array}$ & $\begin{array}{l}9 \\
161\end{array}$ & $\begin{array}{l}5.3 \% \\
94.7 \%\end{array}$ & $\begin{array}{l}0 \\
170\end{array}$ & $\begin{array}{l}0.0 \% \\
100.0 \%\end{array}$ & 9.24 & $<0.05^{*}$ \\
\hline $\begin{array}{l}\text { Incidence of PPH according to } \\
\text { amount of blood in soaked pads } \\
\text { at the first } 1 \text { hour after delivery. } \\
\text { Mild amount (one third of the pad } \\
\text { is covered } \\
\text { Moderate(two one third of the pad } \\
\text { is covered) } \\
\text { Sever( the whole pad is covered }\end{array}$ & 126 & $\begin{array}{l}74.1 \% \\
0.0 \%\end{array}$ & $\begin{array}{l}50 \\
12\end{array}$ & $\begin{array}{l}29.4 \% \\
7.1 \%\end{array}$ & 71.76 & $<0.001 * *$ \\
\hline
\end{tabular}

Table (3):illustrates a highly statistically significant differences between studied subjects at both early and late cord clamping groups in relation to postpartum related outcomes including maternal blood loss, need of woman for manual removal of the placenta , incidence of $\mathrm{PPH},(\mathrm{p}<0.001 * *)$. 
Table (4): Distribution of neonates according to their laboratory investigation .

\begin{tabular}{|c|c|c|c|c|c|c|}
\hline \multirow[t]{2}{*}{ Variables } & \multicolumn{2}{|c|}{$\begin{array}{l}\text { Early cord clamp } \\
\text { group }(n=170)\end{array}$} & \multicolumn{2}{|c|}{$\begin{array}{l}\text { Late cord clamp } \\
\text { group }(n=170)\end{array}$} & \multirow{2}{*}{$\begin{array}{l}\text { Chi } \\
\text { square } \\
\text { test }\end{array}$} & \multirow[t]{2}{*}{ P value } \\
\hline & No & $\%$ & No & $\%$ & & \\
\hline $\begin{array}{l}\text { Neonatal Hemoglobin } \\
\text { level(After } 4 \mathrm{hrs} \text { ) } \\
\text { less than } 14.5 \mathrm{~g} / \mathrm{dl} \\
\text { from } 14.5-22.5 \mathrm{~g} / \mathrm{dl} \\
\text {-Above } 22.5 \mathrm{~g} / \mathrm{dl}\end{array}$ & $\begin{array}{l}91 \\
61 \\
18\end{array}$ & $\begin{array}{l}53.5 \% \\
35.9 \% \\
10.6 \%\end{array}$ & $\begin{array}{l}12 \\
105 \\
53\end{array}$ & $\begin{array}{l}7.1 \% \\
61.8 \% \\
31.2 \%\end{array}$ & 89.50 & $<0.001^{* *}$ \\
\hline $\begin{array}{l}\text { Neonatal Hematocrit level } \\
\text { (After 4hrs) } \\
\text { 1- less than } 45 \% \\
\text { 2- from } 45-65 \% \\
\text { 3- more than } 65 \%\end{array}$ & $\begin{array}{l}38 \\
114 \\
18\end{array}$ & $\begin{array}{l}22.4 \% \\
67.1 \% \\
10.6 \% \\
\end{array}$ & $\begin{array}{l}6 \\
78 \\
86\end{array}$ & $\begin{array}{l}3.5 \% \\
45.9 \% \\
50.6 \% \\
\end{array}$ & 74.48 & $<0.001 * *$ \\
\hline $\begin{array}{l}\text { Neonatal ferritin level } \\
\text { (After 4hrs) } \\
\text { 1-less than } 15 \mathrm{ng} / \mathrm{ml} \\
\text { 2-from } 15-150 \mathrm{ng} / \mathrm{ml} \\
\text { 3-more than } 150 \mathrm{ng} / \mathrm{ml}\end{array}$ & $\begin{array}{l}95 \\
70 \\
5\end{array}$ & $\begin{array}{l}55.9 \% \\
41.2 \% \\
2.9 \%\end{array}$ & $\begin{array}{l}26 \\
72 \\
72 \\
\end{array}$ & $\begin{array}{l}15.3 \% \\
42.4 \% \\
42.4 \% \\
\end{array}$ & 97.67 & $<0.001 * *$ \\
\hline $\begin{array}{l}\text { Neonatal Total Bilirubin } \\
\text { level(After } 4 \mathrm{hrs}): \\
\text { 1-from(.3-1.2)mg/dl } \\
\text { 2-from }(1.2-5) \mathrm{mg} / \mathrm{dl} \\
\text { 3-from }(6-12) \mathrm{mg} / \mathrm{dl}\end{array}$ & $\begin{array}{l}43 \\
104 \\
23\end{array}$ & $\begin{array}{l}25.3 \% \\
61.2 \% \\
13.5 \%\end{array}$ & $\begin{array}{l}33 \\
109 \\
28\end{array}$ & $\begin{array}{l}19.4 \% \\
64.1 \% \\
16.5 \%\end{array}$ & 1.92 & $>0.05$ \\
\hline
\end{tabular}

Table (4): shows a highly statistical significant difference between early and late cord clamping groups regarding neonatal laboratory investigation including hemoglobin ,hematocrit, and ferritin $\left(\mathrm{p}<0.001^{* *}\right)$.in addition no statistical significant difference between them regarding total

bilirubin after 4 hours $(\mathrm{p}>0.05)$.

Figure (1): percentage distribution of the studied neonates in both early and late cord clamping groups regarding their needs neonatal intensive care unit.

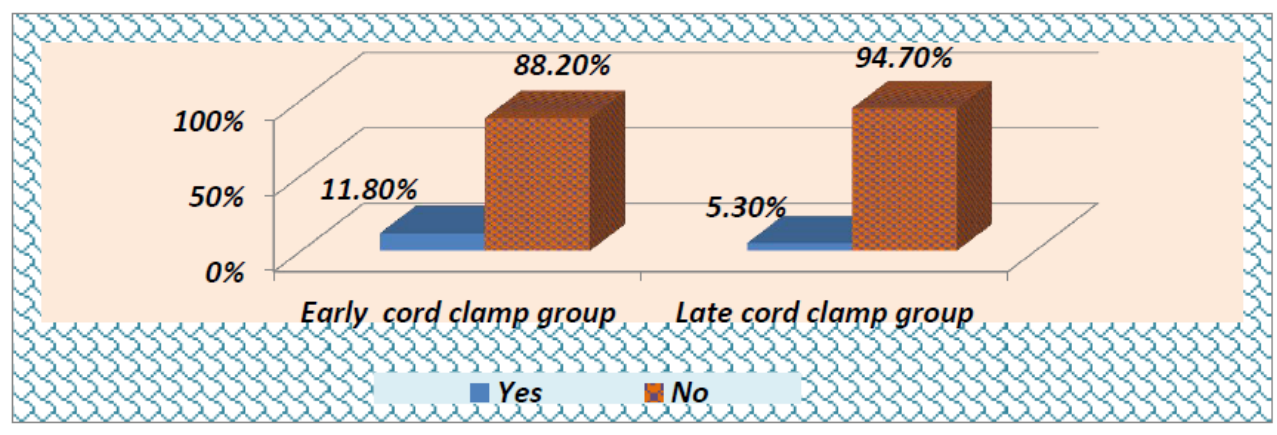




\section{Discussion}

The aim of the current study was to study the effect of early versus late cord clamping of term infants on maternal and neonatal outcomes. This aim supported the research hypothesis that stated late cord clamping in health term neonates increase hemoglobin, hematocrit and ferritin without causing any harm to maternal or neonatal outcomes and doesn't increase the risk of maternal postpartum hemorrhage or duration of the third stage of labour compared with the group with early cord clamping . Several issues regarding effects of DCC as compared to ECC have shown contradictory results, such as risks for maternal $\mathrm{PPH}$, and infants' risk for polycythaemia and jaundice.

Regarding socio-demographic characteristics of the studied sample, the present study showed no statistically significant difference in relation to age, educational qualification ,occupation and residence between both early and late cord clamping. This finding agree with Ahmad et al., (2012) who conducted a randomized controlled trial in El-Minia Maternity University Hospital, Egypt to assess effect of early vs late umbilical cord clamping of term infants on maternal and neonatal outcomes and mentioned that the mean age of the studied sample was $28.31 \pm 5.8$ and the mean age of the studied sample in the present study was $27.58 \pm 7.25$.

As regards the maternal hemoglobin and hematocrite level at birth and after 4 hours, the results of the current study showed no statistically significant differences between early and late umbilical cord clamping ( $p>0.05$ ) . The finding of the present study agreed with McDonald et al., (2013) who conducted systematic reviews and found that Maternal haemoglobin values were not significantly different between women in the early and late cord clamping groups in the days after giving birth. The finding of the present study agreed with Gupta et al.,(2007) who conducted randomized controlled trial in early and late cord clamping and showed no statistically significant differences regarding the maternal hemoglobin and hematocrite .

The result of the present study disagreed with Emhamed et al.,(2010) who found significantly higher regarding maternal hemoglobin in the early clamping group $(11.7 \mathrm{~g} / \mathrm{dl}, \mathrm{SD} 1.3 \mathrm{~g} / \mathrm{dl}$ vs $10.9 \mathrm{~g} / \mathrm{dl}, \mathrm{SD} 1.6 \mathrm{~g} / \mathrm{dl} ; \mathrm{p}=0.0035)$

As regards post- partum hemorrhage the finding of the present study showed a statistically significant difference $\quad(p<0.001)$. This result supported by Stirrat et al., (2012) they conducted a study in Mexico and Argentina and

This result disagreed with McDonald et al., (2013) who conducted systematic reviews and found no significant differences between women in the early and late cord clamping groups (MD $-0.12 \mathrm{~g} / \mathrm{dL}, 95 \% \mathrm{CI}-0.30$ to 0.06 ) at 24 to 72 hours after the birth. This result disagreed with McDonald and Middleton ,(2008) who conducted a Cochrane review of trials and reported no significant differences between early and late cord clamping regarding postpartum haemorrhage or severe postpartum haemorrhage.

As regards the need for manual removal of the placenta, the results of the current study found that about $94,7 \%$ of women in early umbilical cord clamping did not need manual removal of the 
placenta compared to $100 \%$ of women in delayed umbilical cord clamping ( $p>0.05)$. This result is supported by McDonald et al., (2013) who conducted systematic reviews and no significant difference was seen between the early and late cord clamping groups for manual removal of placenta (RR 1.59, 95\% CI 0.78 to 3.26 )

As regards neonatal hemoglobin, hematocrite, and ferritin levels measured after 4 hours after birth, the results of the current study showed a highly statistical significant difference $\mathrm{p}<0.001$ between early and late umbilical cord clamping groups . This results agreed with $\boldsymbol{K c}$ et al.,(2017) who conducted a randomized clinical trial in Nepal and showed that delayed cord clamping reduced the prevalence of anemia at 8 and 12 months of age in a high-risk population. This finding agreed with Andersson et al.,(2011) who conducted a randomized controlled trial in Swedish Country Hospital and reported higher mean ferritin concentration between the two groups $\mathrm{p}<$ 0.001 . This result also agreed with Bolouin et al.,(2013) who conducted a study in Peru and showed Significant benefits of delayed cord-clamping in preventing anaemia were found in infants born to anaemic mothers at both 4 months and 8 months. This finding also agreed with Hutton et al.,(2007) who reported that delayed umbilical cord clamping at birth seems to be safe and can be expected to reduce the prevalence of anaemic newborn babies. The results of the current study regarding neonatal ferritin levels also agree with Cernadas et al., (2010) who reported that Serum ferritin levels were significantly higher in the infants of the three minutes group than in the infants of the early group: 33.2 microg/L vs. 20.9 microg/L. This result agreed with McDonald et al., (2008) who conducted. This result also agreed with Salari et al.,(2014) who conducted a randomized controlled and reported that
Late cord clamping group had greater hematocrit at 2 hours $(45.5 \pm 4$ vs. $49.5 \pm$ $4.4, \mathrm{P}=0.0003)$ and 18 hours $(47.7 \pm 5.5$ vs. $52.9 \pm 4.3, \mathrm{P}=0.0002)$. The result of the present study was inconsistent with Fawzy et al.,(2015) they conducted a randomized controlled study in Shatby Maternity University Hospital, Egypt and found no significant difference between both groups as regarding neonatal hemoglobin. The result of the present study disagreed with Jahazi et al.,(2008) who conducted a randomized controlled trial in Iran and showed that neonatal hematocrit at $2 \mathrm{~h}$ of life $(61+/-4.9$ vs $61.6+/-4.5 \%)$ and $18 \mathrm{~h}$ of life (56.9+/4.1 vs $56.2+/-3.9 \%$ ) was not significant different between the two groups.

\section{Conclusion:}

In the light of the main study findings and research hypothesis, It is concluded that delayed cord clamping increase hemoglobin, hematocrite and ferritin level without causing any harm to maternal or neonatal outcomes, doesn't cause pathological jaundice, doesn't decrease maternal hemoglobin and hematocrite at birth and after 4 hours, doesn't increase duration of labour stages, and doesn't increase the risk of postpartum hemorrhage. Finally, the present study supported the study research hypothesis and achieved aim of the study.

\section{Recommendation :}

Based on the findings of the present study, the following recommendations are suggested:

- Delayed cord clamping is recommended to be practiced policy and supported by university hospital 
- Design awareness program for pregnant women about the benefits of delayed cord clamping

- Apply the same study in large sample size in different settings .

\section{References}

Abd El- Moneim, F., Moustafa, A., ElKassar, Y., Swelem, M., El-Agwany, A., Diab, D., (2015): Early versus delayed cord clamping of term birth in Shatby Maternity University Hospital, Prog Obstet Gynecol. 2015;58(9):389392.

Ahmed, E., Ali, s., Zahran, K.,(2012): Effect of Early versus Late Cord Clamping of Term Infants on Maternal and Neonatal Outcomes. Journal of American science;8(9)745:752.

Andersson, O., Westas, L., Andersson, D., Domellof, M.,(2011): Effect of delayed versus early umbilical cord clamping on neonatal outcomes and iron status at 4 months: A Randomized Controlled Trial. British Medical Journal.; 343:d7157.DOI: 10.1136/bjm.d7157.

Bolouin ‘B., Penny, M ‘.Maheu.Giroux ، M ‘.Casapia ‘M., et al.,(2013 :(Timing of umbilical cord clamping and infant anemia: The role of maternal anemia . Paediatr Int Child Health;33(2):79-85. DOI:

10.1179/2046905512Y.0000000036.

Brucker ‘M :(2009) '.Management of the third stage of labour : an evidence based approach. Journal of Midwifery and Women's Health;46(6): 381-92

Ceriani-Cernadas, J., Carroli, G., Pellergrini, L., Ferreira, M., Ricci, C.,
Casas, O., et al.,(2010): The effect of early and delayed umbilical cord clamping on neonatal venous hematocrit values and clinical outcome at term: a randomized, controlled trial. Pediatrics ;117:779-86

Eichenbaum-Pikser, G., Zasloff,J.,(2009): Delayed Clamping of the Umbilical Cord: A Review with implications for practice. Journal of Midwifery\& Women health;54:321-326.

Emhamed, M., Van Rheenen, P., Brabin, B.,(2010): The early effects of delayed cord clamping in term infants born to Libyan mothers. Trop Doct ;34:218-22.

Gupta, R \& Ramji, S.,(2012): Effect of delayed cord clamping on iron stores in infant born to anemic mothers: a randomized controlled trial. Indian Pediatrics;39(2):130-5

Hooper,S., Te Pas, A., Lang, L., et al.,(2015). Cardiovascular transition at birth : a physiological sequence. Pediatr Res.;77:608-14. DOI:10.1038/ pr.2015.21.

Hutton, E., Hassan, E.,(2007): late vs early clamping of the umbilical cord in full - term neonates: systematic review and meta- analysis of controlled trials .JAMA . ;297:12411252.

International Confederation of Midwives (ICM),International federation of Gynecologists and Obstetricians (FIGO) . (2006) :Joint statement :management of the third stage of labour to prevent post-partum hemorrhage ,

http://www.pphprevention .org/index . php (accessed fed 4,2017) 
Jahazi, A., Kordi, M., Mirbehbahani, V., Mazloom, S., (2008): The effect of early and late umbilical cord clamping on neonatal hematocrit. Journal of perinotology;28(8): 423-5.

Kc, A., Rana, N., Malqvist, M., Andersson, O., et al.,(2017): Effect of delayed umbilical cord clamping vs early clamping on anemia in infants at 8 and 12 months: A Randomized Clinical Trial; JAMA Pediatr; $1 ; 171(3): 264-$

270.doi:10.1001/jamapediatrics.

McDonald, S.,\& Abbott, J.,(2008): Effect of timing of umbilical cord clamping of term infants on maternal and neonatal outcomes. Cochrane Database of Systematic Reviews;1:105-15.

McDonald, S.,\& Middleton, P.,(2008): Effect of timing of umbilical cord clamping of term infants on maternal and neonatal outcomes Database of systematic Reviews Issue2. Art :CD004047.DOI:10.1002/14651858.

McDonald, S.,\& Middleton, P., Dowswell, T., Morris, P.,(2013): Effect of timing of umbilical cord clamping of term Infants on maternal and neonatal outcomes. Cochrane Database of systematic Reviews,Issue7.[DOI: 10.1002/14651858.CD004074]

Mercer, J., Vohr, B., Erickson-Owens, D., Padbury, J., Oh, W.,(2008): Sevenmonth development outcomes of very low birth weight infants enrolled in a randomized controlled trial of delayed versus immediate cord clamping. J Perinatal.2008;30(1):11-16.

Salari, Z., Rezapour, M., Khalili, N., (2014): Late umbilical cord clamping , neonatal hematocrit and Apgar scores: a randomized controlled trial. J Neonatal Perinatal Med.;7(4)28791.DOI:10.3233/NPM-1463913.

World Health Organization (WHO),(2012):Guidelines on Basic Newborn Resuscitation: Geneva.

WHO.(2012): WHO Recommendations for the prevention and treatment of postpartum Hemorrhage: Evidence Base. WHO: Geneva. Available

At:www,who.int/reprouductivehealth/pub lication/maternal_perinatal_health/978 9241548502/en 